a great loss; and all efforts to build up towns away from railroads are perfectly futile. But the opposite of this is shown along the line of all railroads, in the increased price of farms, and in the rapid increase in growth of towns, and prices of property. This is but a natural and unavoidable result; for the necessary and acquired business of the road itself produces life and stir at all their stations, attracting and drawing there, and making therein the center of all mechanical, mercantile, manufacturing, and grain and stock dealing operations of that vicinity. Therefore, the people being watchful of their interest, will take immediate steps for the making of said railroad, even if it should require half their real estate to do it; for, one-half with the road, will be worth more than all without, and the attention of capitalists seek opportunities for investment and business, through this new channel and convenience for freighting by railroad and river, and Louisa county go on to prosper, and be prospering.

(To be continued.)

\title{
SQUATTERS AND SPECULATORS AT THE FIRST LAND SALES.
}

BY HAWKINS TAYYLOR.

Previous to the survey of lands in Iowa, even to the survey of the base and township lines, what was known as the Black 2 Hawk purchase (as described in a former number of your paper), was mainly taken up and settled upon by what was then designated as "squatters." There were then no homestead laws, as now, not even pre-emption laws. The settlers had to be a law unto themselves, to protect their own homes and firesides. To do this previous to the lands being offered for sale, the settlers in each township met and adopted their own bylaws, by which each settler was allowed to hold three hun- 
dred and twenty acres of land, by settling on the same, or making certain improvements thereon; they also appointed a committee of five or seven, to settle all disputes, which were numerous, mainiy growing out of the fact that nearly all of the claims were made before the lands were surveyed, and seldom agreeing with the claim lines. Often the house of one settler and the farm of another would be on the same one hundred and sixty acres, by the government survey. This township committee prepared a township map, and registered each settler's claim as he claimed to have located it, and so on until all the settlers in the township filed their claims, when the committee would cite before them all parties contestants, and have each party bring his witnesses and give all the facts in his case. Each party and all the witnesses told their own story, on the honor of seitlers; none were sworn; there was no need of swearing men at that day to get the truth. The committee would then decide the case, and correct the register accordingly, and from that decision there was no appeal, and I never knew of injustice being done in a single case. After this registration was made, a bidder was appointed for each township, who bid off at the land sale each tract of land to the party to whom it was registered, and, in cases where more than one man's claim was embraced in the same tract, the person to whom it was bir off would deed to the proper claimant the amount belonging to him, he paying his proper share of the purchase-money. In this way, every man was fully protected in his rights. The law never did and never can protect the people in all their rights, so fully, and so completely, as the early settlers of Iowa protected themselves by these organizations, doing justice to all, as well as paying the government fully for the landa occupied by them.

The land officers at Burlington, General Van Ant xerp and General Dodge, most heartily entered into the spirit and interests of the settlers at the land sales in securing them their lands, for which these early settlers honored Gen. Dodge, politically, as few men were ever trusted by any people. Gen. 
Van Antwerp, fortunately, or unfortunately for himself, as a politician, never went to the people for office; he was of the old Knickerbocker chivalry - was educated at West Point, and always wore a boiled shirt and starched collar - full of grit, but always true, but never of the masses. God bless, as He will surely do, the "old settlers," generally and collectively, of that day.

Strange as it may seem to people at this day of free lands to all who will go and settle upon them, at that day, the settlers on public lands were held as squatters, without any rights to be respected by the government or land speculators. Many amusing incidents happened at these sales; one I will relate: There were thousands of settlers at the sale at Burlington, in the fall of 1838 ; the officers could sell but one or two townships each day, and when the land in any one township was offered, the settlers of that township constituted the army on duty for that day, and surrounded the office for their own protection, with all the other settlers as a reserve force, if needed. The hotels were full of speculators of all kinds, from the money loaner, who would accommodate the settler at fifty per cent, that is, he would enter the settler's land, in his own name, and file a bond for a deed at the end of two years, by the settler paying him double the amount the land cost. At these rates, Dr. Barrett, of Springfield, Illinois, and Louis Benedict, of Albany, New York, loaned out one hundred thousand dollars each, and Lyne Sterling, and others, at least, an equal amount, at the same, or higher rates of interest. The men who come to Iowa now cannot realize what the early settlers had to encounter. The hotels were full of this and a worse class of money sharks. There was a numerous class who wanted to rob the settlers of their lands and improvements entirely, holding that the settler was a squatter and trespasser, and should be driven from his lands. You would hear much of this sort of talk about the hotels, but none about the settlers' camps. Amongst the loudest talkers of this kind was an F. F. V. a class that has now about "give out." This valiant gentleman was going to invest his money as he pleased, 
without reference to settlers' claims. When the township of West Point was sold it was a wet, rainy day; I was bidder, and the officers let me go inside of the office. Just when I went into the office, Squire John Judy, who lived on section thirty-two or thirty-three, whispered to me that he had been disappointed in getting his money, at the last moment, and asking me to pass over his tract and not bid it off. I did so, but this Virginian bir! it off. I was inside, and conld not communicate to any one until the sale was through, and, as I did not bid on the tract, the outsiders supposed that it $\mathrm{I}$ as not claimed by a settler, and the moment the bid was made, the bidder left for his hotel. As soon as I could get out, which was in a few minutes, and make known that Judy's land had been bid off by a speculator, within five minutes time, not less than fifteen hundred of as desperate and determined a set of men as ever wanted homes, started for the bold bidder. Prominent in the lead was John G. Kennedy, of ${ }^{\checkmark}$ Fort Madison, who enjoyed such sport. Col. ${ }^{\vee}$ Patterson, now of Keokuk, a Virginian by birth, but a noble, true-hearted friend of the settler, and who had been intimate with the Virginian, made a run across lots, and reached the hotel before Kennedy and his army. The Colonel informed the bidder of the condition of affairs, and advised him at once to abandon his bid, which he did, or, rather, he authorized the Colonel to do it for him. The Colonel went out and announced to the crowd that the bid was withdrawn, and that the bidder had also withdrawn himself. Both offers were accepted, but the latter was bitterly objected to, and only acquisced in when it was found that the party had escaped the back way, and could not be found; there was no other remedy. This was the last outside bid given during that sale, and you heard no more talk about outside bidding, about the hotels. The squatters' rights were respected at that sale.

The secretary of the territory, with Chambers, was O. H. W. Stull, of Cumberland, Maryland, in place of Virginia; he was Chambers's brother-in-law, eccentric, but high-toned and honorable. At the end of his term he returned to his old 
home and served as justice of the peace, with credit to himself, up to his death, but a few years since. Many amusing anecdotes could be told of him, of a piece with the one named by Negus.

The first whig territorial convention held was in May or June, 1840 , in Muscatine ; it was a mass convention to nominate a candidate for Congress. There was a large delegation from Lee and Des Moines counties. The candidates for nomination were Alfred ${ }^{V}$ Ritch and Philip Viele, both lawyers, and citizens of Fort ${ }^{\mathrm{V}} \mathrm{Madison}$, and both men of ability. Pitch was one of the brightest young men in the territory, but fell an early victim to consumption. Judge Viele still lives at his old home, in Fort Madison, rich and honorable. The contest was exciting, and alimost bitter. Ritch was the pet of the young America of his party, while the Judge was rather the representative of whig respectability. One delegation from the south numbered about sixty, and camped the first night at Wapello, Louisa county. The next morning, a few miles below Muscatine, in passing a house a red petticoat was thrown out as a slur on Gen. Harrison, the whig candidate for president; the delegates made a charge on the red flag, headed by the redoubtable "Sile "Hudson," now minister abroad, The flannel was captured, and the delegation passed on. There was great enthusiasm at the convention. Ritch was nominated, but beaten by General A. C. 'Dodge, the democratic candidate, by a few hundred votes.

I will give one case, of hundreds and thousands that could be given, of the hardships of the early settlers: Alexander

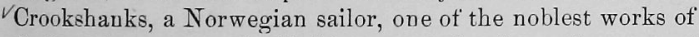
God, an honest man in all things, settled a few miles west of West Point, in Lee county, in 1835 , and, by hard work, made him a large farm. When the sale of his land was ordered by the government, he went to western New York and borrowed four hundred dollars of his brother, to enter his land. This was when. Martin Van Buren's specie circular was in force, and certain designated banks were made government depositories by the government. Crookshanks, to be certain 
that his money was "land office money," when he got home, paid a premium of three per cent in New York, to get the bills of a city bank that was a government deposit bank. His brother gave him thirty-four dollars to pay his expenses home. At that time there were no railroads. Alex walked to Pittsburgh and there took a boat for St. Lonis; but when he got to New Albany, Indiana, the Ohio river was so low that there was no certainty of getting to St. Louis in time to get home by the day of the sale of his land, ancl he had no money to spare to go by stage. So he, on foot, crossed Indiana and Illinois, reaching home the Friday before the sale on Monday; and when he went to Burlington, he found that his New York money would not be taken by the land office, and he had to shave off his money that he had already paid a premium for, to get "land office money" for "land office money" and pay another premium of twelve and a half per cent, reducing his four hundred to three hundred and fifty dollars. To make up this fifty, he had to sell off a part of his scanty stock at less than one-fifth of what the same kind of stock would sell for now. I recollect the day Alex started to New York to borrow the money to enter his land with, asking him what he would do if he tailed; his answer was, "I will come home and try to borrow at the sale, but if I fail, and lose my land, I will cross the Rocky mountains but what I will have and own my own land." Of such stuff were the early settlers. Why should not the state be great and noble now? 
Copyright of Annals of Iowa is the property of State of Iowa, by \& through the State Historical Society of Iowa and its content may not be copied or emailed to multiple sites or posted to a listserv without the copyright holder's express written permission. However, users may print, download, or email articles for individual use. 